Acta vet. scand. $1986,27,505-519$.

From the Department of Animal Reproduction and the Department of Anatomy, Royal Veterinary and Agricultural University, Copenhagen, Denmark.

\title{
CHRONOLOGICAL CHANGES OF BOVINE FOLLICULAR OOCYTE MATURATION IN VITRO*
}

\author{
By \\ K. P. Xu, T. Greve, S. Smith and P. Hyttel
}

\begin{abstract}
XU, K. P., T. GREVE, S. SMITH and P. HYTTEL: Chronological changes of bovine follicular oocyte maturation in vitro. Acta vet. scand. 1986, 27, 505-519. - Chronological changes of bovine follicular cumulus-oocyte-complexes were studied after in vitro maturation over a period of $48 \mathrm{~h}$. According to their thickness and compactness of cumulus investments they were classified into 4 groups and cultured in enriched Ham's F-10 medium with or without human chorionic gonadotrophin (hCG) and estradiolbenzoate (EB) for $0,6,12,18,21$, $24,27,30$ and $48 \mathrm{~h}$. Representative samples were taken at each time interval for evaluation of nuclear maturation stages, ooplasm quality and size of the perivitelline space (PVS). The results showed that oocyte nuclear breakdown (ONBD) required 6 to $12 \mathrm{~h}$ culture, and the peak of the first polar abstriction occurred at $24 \mathrm{~h}$. The culture period required for ONBD and abstriction of the first polar body were related to the thickness and compactness of cumulus investments with and approximately $6 \mathrm{~h}$ delay in heavily compacted complexes. Ooplasm quality evaluation failed to show a clear trend, but the PVS increased in size from $0 \mathrm{~h}$ to $30 \mathrm{~h}$ and then retracted again from 30 to $48 \mathrm{~h}$. The overall maturation rate in the presence of hCG and EB was $79.1 \%$, and a substantial proportion $(68.8 \%)$ of nude or partially covered oocytes reached metaphase II stage. In the presence of $\mathrm{hCG}$ and EB no block at either metaphase I or at anaphase-telophase I was observed. In the absence of hCG and EB the percentage of oocytes reaching metaphase II was much lower $(\mathbf{4 8 . 6 \% )}$ in comparison with oocytes matured in the presence of these hormones $(79.1 \%)$. It was concluded a very high proportion of slaughterhouse oocytes could be matured in vitro and that the cumulus investments and addition of certain hormones affected the maturation rate.
\end{abstract}

nuclearmaturation; hormones; cumulus; cattle.

* This work was supported by grants from Danish Veterinary and Agricultural Research Council and Lee Research Foundation. 
Most of mammalian oocytes including those of cattle mature in vitro when they are released from the follicular environments and placed in suitable culture media (Edwards 1965). The in vitro maturation events and the biochemical components involved in meiosis are poorly understood despite considerable research efforts in recent years (Jagiello et al. 1974, Sato et al. 1978, Fulka et al. 1981, Süss \& Wüthrich 1985, Motlik \& Fulka 1986, Eppig \& Schroeder 1986).

The only reliable criteria for normal oocyte maturation are fertilization in vitro and subsequent development of the fertilized egg into live offspring (Moor et al. 1981, Hensleigh \& Hunter 1985, Leibfried-Rutledge et al. 1985). However, the developmental capacity of most in vitro matured oocytes is low (Ball et al.1984) and only recently has a pregnancy been established following in vitro fertilization of in vitro matured oocytes (Critser et al. 1986). Even in vivo matured oocytes have low survival rates following in vitro fertilization (Greve et al. 1984, Lambert et al. 1986).

There is still a need for more detailed studies of the requirements for and the conditions that allow proper in vitro maturation of bovine oocytes, and the aims of the present study are: (1) to establish a detailed chronology of the nuclear maturation of bovine oocytes cultured in vitro for different periods of time, and (2) to examine if certain factors such as hormones could influence this nuclear maturation process.

\section{MATERIALS AND METHODS}

\section{Oocyte collection}

Ovaries were obtained from cows within $30 \mathrm{~min}$ after slaughter at a local abattoir. Follicular contents from small visible antral follicles (approx. 1-6 $\mathrm{mm}$ in diameter) were aspirated and placed in a conical centrifuge tube containing $4 \mathrm{ml}$ Hepes buffered Ham's F-10 (F-10), supplemented with $20 \%$ heat treated foetal calf serum (FCS), $0.4 \mathrm{mmol} / \mathrm{l}$ glutamine, and 50 I.U. penicillin and $50 \mu \mathrm{g}$ dihydrostreptomycin per $\mathrm{ml}$. The tubes were kept at $30-38^{\circ} \mathrm{C}$. After 30 to $40 \mathrm{~min}$ the sedimented oocytes with their cumulus investments were transferred to fresh medium of the same composition. To establish a zero hour control group follicular contents were stored without medium at $0^{\circ} \mathrm{C}$ until evaluation and fixation, 


\section{Oocyte evaluation and selection}

Within 2 to $3 \mathrm{~h}$ of collection the oocytes were brought to the laboratory, washed 3 times in fresh medium and evaluated under a stereomicroscope. In Exp. I (a and b) pools of oocytes were assigned into 4 groups based upon their gross morphology and the integrity of the cumulus cells. The features and descriptions of different groups are shown on Plate 1, Figs. 1 to 5 . No attempt was made to classify the ooplasm quality of groups I, II and III due to the thick layers of cumulus cells that made proper evaluation impossible. Oocytes with shrunk, vacuolated ooplasm or with other signs of degeneration were excluded from group IV. In Exp. II only healthy looking oocytes with more than $2-3$ layers of cumulus were included.

\section{Oocyte culture}

The onset of culture time was defined as the mean time of the oocyte collection period. The medium used for oocyte culture was identical to the F-10 used for the collection with the exception, that it was bicarbonate buffered. In Exp. $I_{b}$ no further supplementation was done while in Exp. $\mathrm{I}_{\mathrm{a}}$ and Exp. II 2 I.U. hCG (Physex, Leo, Denmark) and 1 g g estradiolbenzoate (Ovex, Leo, Denmark) were added per $\mathrm{ml}$. Culture was performed in 4 well multidishes, at $38^{\circ} \mathrm{C} / 5 \% \mathrm{CO}_{2}$ in humidified air for $0,6,12$, 18, 24, 30 and $48 \mathrm{~h}$ (Exp. $\mathrm{I}_{\mathrm{a}}$ and Exp. $\mathrm{I}_{\mathrm{b}}$ ), and 21, 24 and $27 \mathrm{~h}$ (Exp. II). For each group, 10 to 15 oocytes were placed in $1.0 \mathrm{ml}$ medium which was filtered through a $0.22 \mu \mathrm{m}$ milipore filter and equilibrated in $5 \% \mathrm{CO}_{2}$ for at least $3 \mathrm{~h}$ prior to cultivation.

\section{Oocyte evaluation before fixation}

After various periods of culture, oocytes were sampled and the cumulus cells were removed with trypsin (original TrypsinEDTA solution, GIBCO U.K.) along with repeated pipetting. The denuded oocytes were mounted on grease free slides and examined under a stereomicroscope. Oocytes were classified accarding to the size of the PVS as: absent, small, medium and large. Based upon the character of the ooplasm, three oocyte types could be defined. Those with finely granulated and evenly distributed organelles were regarded as type I, and those that were more coarsely granulated with unevenly distributed organelles and some vacuolation were designated as type II. Large 
vacuoles and shrunken ooplasm were indicative of degeneration and these oocytes were classified as type III. Following this stereomicroscopic evaluation oocytes were fixed in methanol: acetic acid $(3: 1)$ for at least $48 \mathrm{~h}$, and then stained with $1 \%$ aceto-orcein for the final examination.

Oocyte evaluation after fixation

After fixation and staining, oocyte nuclear maturation was evaluated under interference phase contrast microscope $(320 \times)$ to define the meiotic stages as follows.

Oocyte nucleus stage I (ON I): Oocytes had a distinct nuclear envelope, chromatin was only around the nucleolus, which may not always be present ,and/or in the appearence of a few orcein-positive zones.

Oocytes nucleus stage II (ONII): The nuclear envelope was still present but less distinct, the chromatin was distributed in separate, well stained clumps or the individual filamentous bivalents were distinguishable.

D i a kin ess is (D): The nuclear envelope was no longer visible, and the bivalents remained within the area of the oocyte nucleus.

L a te diakinesis (L D): The oocyte nucleus area had totally disappeared and the bivalents were further condensed.

M et a phas e I (M I): The chromosomes were maximally condensed, and sometimes present as a whole clump from an equatorial view.

An a phas e-Telophas e I (A-T I): The chromosomes were under division or segregation, and the membrane of the first polar body might be present but the spindle was still not detached.

Metaphase II (M II): The contracted metaphase chromosomes and the first polar body were both present.

If none of the above mentioned nuclear features were identified in the preparation, the oocytes were classified as Non-Defined (ND). 
K. P. Xu, T. Greve, S. Smith and P. Hyttel: Chronological Changes of Bovine Follicular Oocyte Maturation in Vitro.
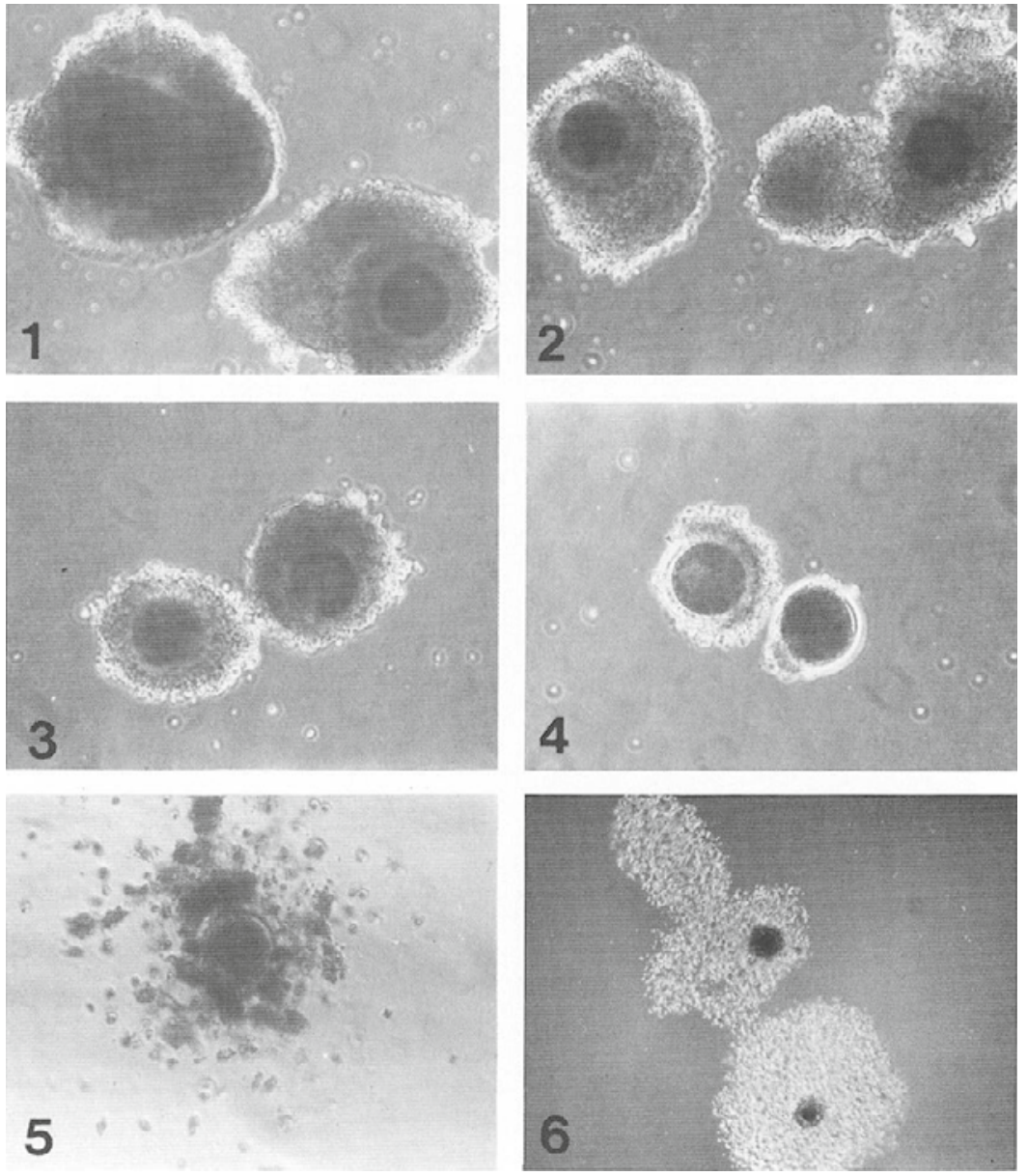

$\mathrm{Pl}$ a t e 1. Morphologival appearance of cumulus-oocyte-complexes before and after culture.

Fig u re 1. (Group I): Oocytes with tight, completely compacted cumulus investments $(70 \times)$.

Fig u re 2. (Group II): Oocytes with complete but not tightly compacted cumulus investments $(70 \times)$.

F i g u re 3. (Group III): Oocytes with only a few layers of cumulus cells $(70 \times)$.

F i g u r e 4. (Group IV): Oocytes with only partial or none cumulus investments $(70 \times)$.

Figure 5. Oocytes with degenerated cumulus investments. Note that cumulus cells are coalesced in scattered clumps. These oocytes were not included in the experiment $(70 \times)$.

Fi g u r e 6. Typical morphological appearance of oocytes after culture for $30 \mathrm{~h}$, showing expanded cumulus investments $(20 \times)$. 

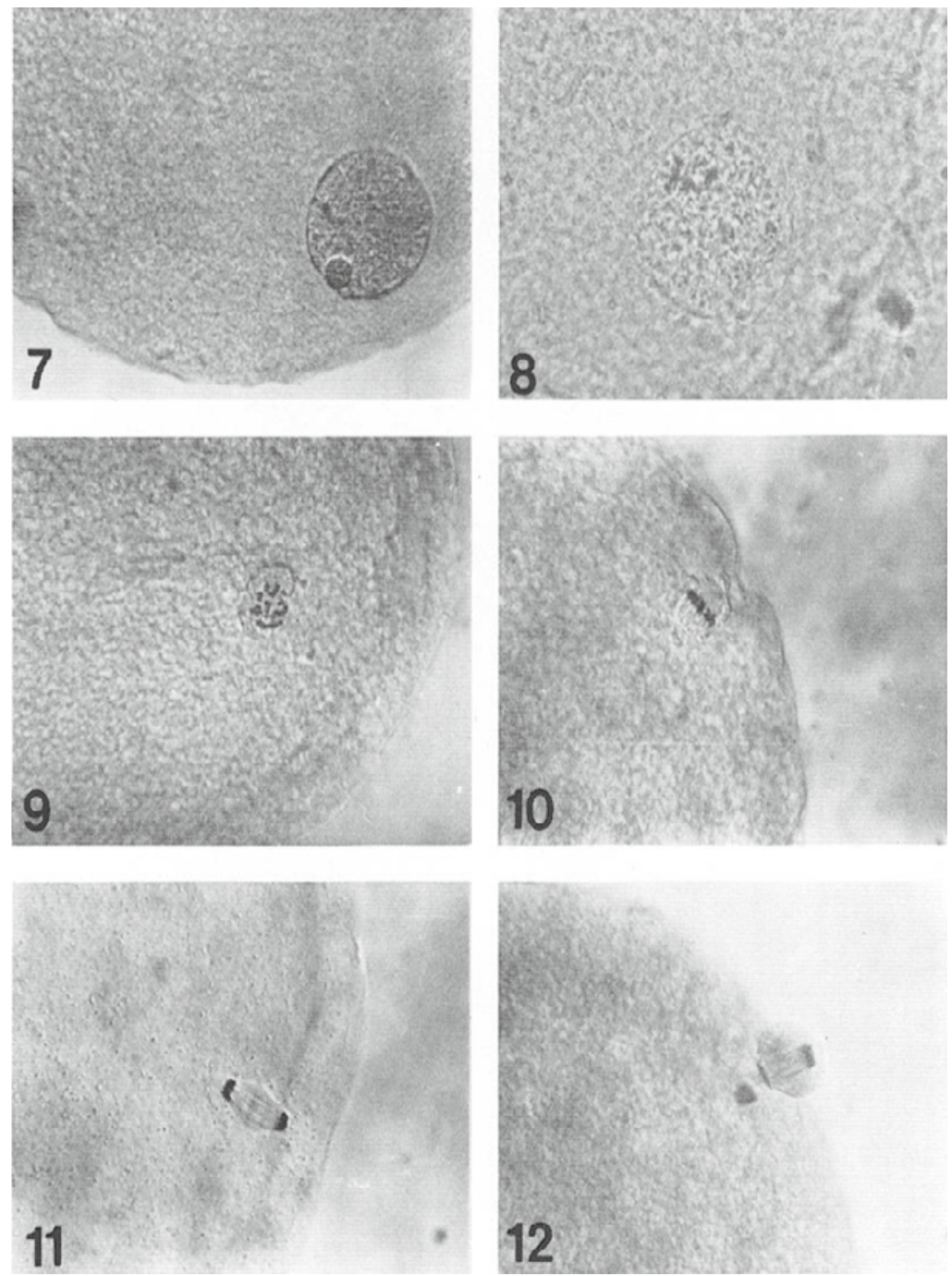

P. 1 a t e 2. Representative examples of meiotic stages.

Figure 7. Oocyte nucleus stage I $(\mathrm{ON}$ I) $(300 \times)$.

Fig u re 8. Oocyte nucleus stage II (ON II) $(300 \times)$.

Figu re 9. Diakinesis (D) $(300 \times)$.

Figure 10 . Metaphase I (M I) $(300 \times)$.

Figure 11 . Ana-Telophase I (A-T I) $(300 \times)$.

Fi gu re 12 . Metaphase II with first polar body (M II) $(300 \times)$. 


\section{RESULTS}

\section{Chronological changes of oocyte maturation}

Photographic examples of the progressive meiotic stages are shown in Plate 2 (Figs. 7-12) and Table 1 depicts the distribution of meiotic stages over the culture periods, i.e. from 0 to 48 $h\left(n=374, \operatorname{Exp} . I_{a}\right)$. The data in the table are based upon the identified oocytes, since the number of ND oocytes within each group were similiar, therefore, they were not included.

T able 1. Cytological changes of bovine oocytes cultured in vitro $\left(\operatorname{Exp}-\mathrm{I}_{\mathrm{a}}\right)$.

\begin{tabular}{|c|c|c|c|c|c|c|c|c|}
\hline \multirow{2}{*}{$\begin{array}{l}\text { Culture } \\
\text { period } \\
\text { (h) }\end{array}$} & \multirow{2}{*}{$\begin{array}{c}\text { No. of } \\
\text { identified } \\
\text { oocytes }\end{array}$} & \multicolumn{7}{|c|}{ Meiotic stages $(\%)^{1}$} \\
\hline & & ON I & ON II & D & LD & M & A-T I & M II \\
\hline 0 & 75 & 69.3 & 25.3 & 4.0 & 1.3 & 0 & 0 & 0 \\
\hline 6 & 35 & 8.6 & 22.9 & 60.0 & 8.6 & 0 & 0 & 0 \\
\hline 12 & 39 & 5.1 & 2.6 & 28.2 & 53.8 & 7.7 & 2.6 & 0 \\
\hline 18 & 64 & 1.6 & 1.6 & 4.7 & 26.6 & 15.6 & 25.0 & 25.0 \\
\hline 24 & 67 & 0 & 0 & 0 & 6.0 & 7.5 & 7.5 & 79.1 \\
\hline 30 & 54 & 1.9 & 0 & 5.6 & 5.6 & 14.8 & 1.9 & 70.4 \\
\hline 48 & 40 & 0 & 0 & 0 & 0 & 70.0 & 0 & 30.0 \\
\hline
\end{tabular}

1 The meiotic stages are defined under Materials and Methods.

At the time of collection $(0 \mathrm{~h})$ the majority of oocytes $(95 \%)$ were at the oocyte nucleus (ON) stages. Approximately two thirds were at ON I $(69.3 \%)$, and one fourth $(25.3 \%)$ had shown some chromosome condensation which was classified as at the ON II. Only $5 \%$ of the oocytes did not possess an ON.

At $6 \mathrm{~h}$ of culture, $69 \%$ of the oocytes had undergone ONBD. At $12 \mathrm{~h} 92 \%$ of oocytes showed ONBD, and most of them were at diakinesis or late diakinesis stage. The earliest of frist polar body abstriction was seen at $15 \mathrm{~h}$. At $18 \mathrm{~h} 25 \%$ of oocytes had extruded their first polar body, and the meiotic stages showed a most variable picture. The peak level (79\%) of polar body presentation occurred at $24 \mathrm{~h}$. Following further culture, some of the polar bodies began to degenerate and disappear, as indicated by the declining percentage of M II after the peak level of $24 \mathrm{~h}$. Only $30 \%$ of oocytes had retained their first polar body at $48 \mathrm{~h}$.

Table 2 shows the result of the Exp. II, i.e. the meiotic stages around the time of first polar body abstriction in 260 oocytes. At $21 \mathrm{~h}$, approximately $20 \%$ of oocytes were at A-T I, and 
T a b l e 2. Cytological changes of oocytes around the time of abstriction of the first polar body (Exp-II).

\begin{tabular}{cccccc}
\hline \multirow{2}{*}{$\begin{array}{c}\text { Culture } \\
\text { periods } \\
\text { (h) }\end{array}$} & \multirow{2}{*}{$\begin{array}{c}\text { No. of } \\
\text { identified } \\
\text { oocytes }\end{array}$} & \multicolumn{4}{c}{${\text { Meiotic stages }(\%)^{1}}^{1}$} \\
\cline { 3 - 6 } & & Prometaphase $^{2}$ & M I & A-T I & M II \\
\hline 21 & 157 & 8.3 & 10.8 & 19.7 & 61.1 \\
24 & 51 & 5.9 & 5.9 & 5.9 & 82.4 \\
27 & 52 & 1.9 & 28.8 & 1.9 & 67.3 \\
\hline
\end{tabular}

1 The meiotic stages are defined under Materials and Methods.

2 Prometaphase refers to ON I, ON II, D and LD.

following an additional $6 \mathrm{~h}$ culture only $2 \%$ remained at this stage. The number of M II with polar body occurred $24 \mathrm{~h}$, the same as in Exp. $I_{a}$ (Table 1).

During the $48 \mathrm{~h}$ of culture period, no apparent changes, such as vacuolization or uneven distribution of organelles, were observed in the ooplasm. However, there was a tendency towards a more finely granulated ooplasm, i.e. from type II ooplasm to type I ooplasm.

The size of the PVS changed during the culture period. At $0 \mathrm{~h} 85 \%$ of oocytes had no visible PVS. As the culture proceeded the PVS became gradually enlarged, and reached a maximum size at $30 \mathrm{~h}$. Subsequently, the PVS retracted or decreased in size.

\section{Effects of cumulus investments on oocyte maturation}

The meiotic stages of the oocytes grouped according the morphology of the cumulus investments are shown in Table 3. At $0 \mathrm{~h}$ only group III oocytes exhibited ONBD. By $6 \mathrm{~h}$ of culture a majority of group II $(93.3 \%)$ and group IV $(85.7 \%)$ oocytes had lost their ON, while approximately two thirds of group I and II oocytes retained theirs. At $12 \mathrm{~h}$ of culture none of group III and IV oocytes had ON, whereas one fourth of group I oocytes still possessed theirs (Fig. 13).

The time required for oocytes to reach the final nuclear maturation was also affected by cumulus investments. At $18 \mathrm{~h}$, $40 \%$ of group III oocytes had extruded their first polar bodies, and the peak level of first polar presentation appeared at $24 \mathrm{~h}$. Group II and IV matured slower and exhibited a lower percentage of polar body formation than group III, but they reached the peak level at $24 \mathrm{~h}$, i.e., at the same time as group III. Group I oocytes matured at the slowest rate and reached the peak level 
(\%)

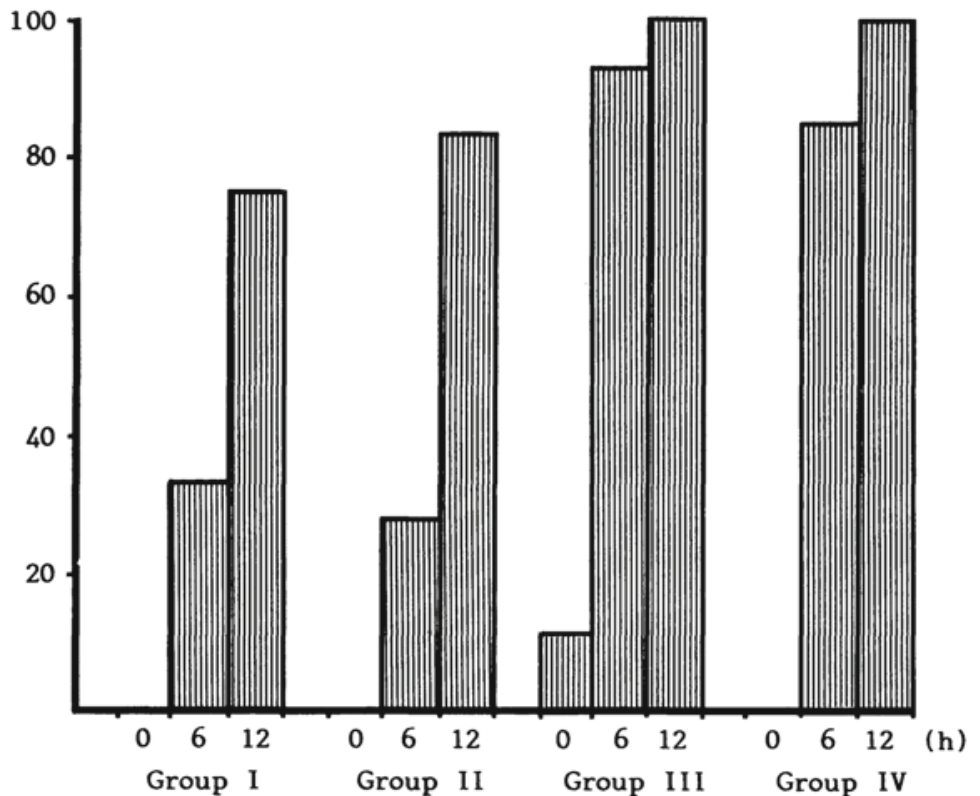

Figure 13. Time of oocyte nucleus breakdown (ONBD) of the 4 oocyte groups cultured in vitro.

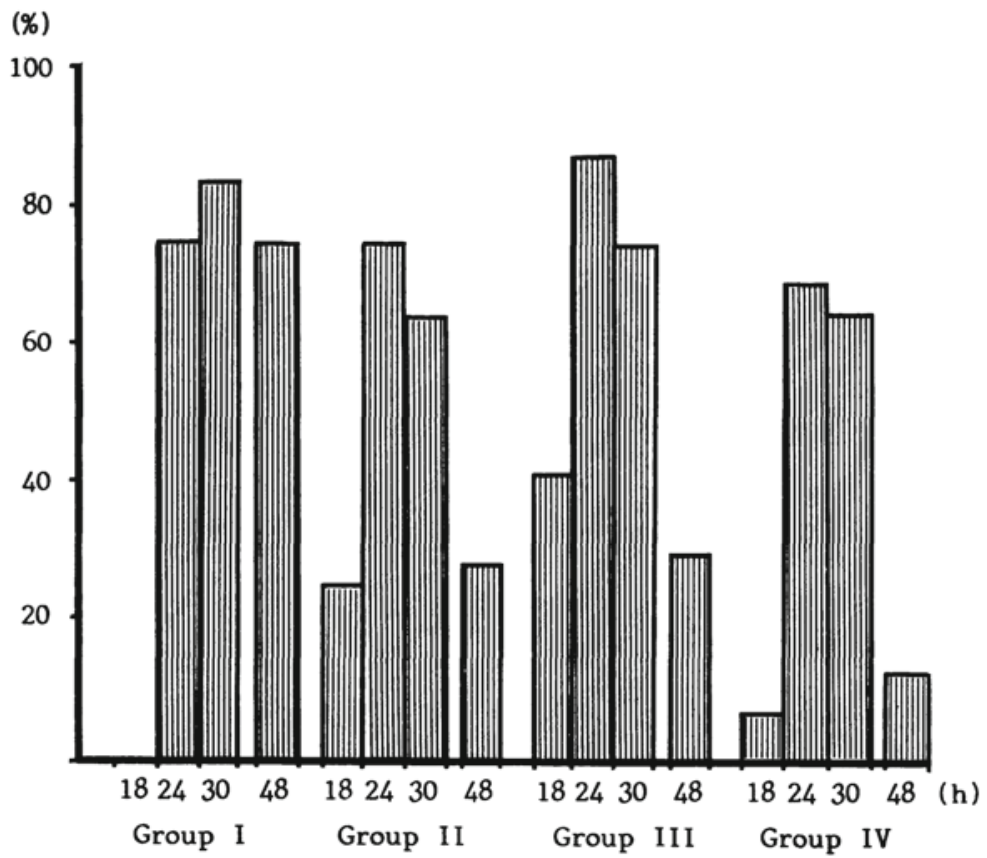

Figure 14. Time of first polar body appearance of the 4 groups of oocytes cultured in vitro. 
T a b le 3. Cytological features of the 4 cumulus groups of oocytes cultured in vitro $\left(\operatorname{Exp}-\mathrm{I}_{\mathrm{a}}\right)$.

\begin{tabular}{|c|c|c|c|c|c|c|c|c|c|}
\hline \multirow{2}{*}{$\begin{array}{l}\text { Cumulus } \\
\text { group }\end{array}$} & \multirow{2}{*}{$\begin{array}{l}\text { Culture } \\
\text { period } \\
\text { (h) }\end{array}$} & \multirow{2}{*}{$\begin{array}{c}\text { No of } \\
\text { oocytes } \\
\text { evaluated }\end{array}$} & \multicolumn{7}{|c|}{ Meiotic stages $(\%)^{1}$} \\
\hline & & & ON I & ON II & $\mathbf{D}$ & LD & M I & A-T I & M II \\
\hline \multirow[t]{7}{*}{ I } & 0 & 11 & 72.7 & 27.3 & 0 & 0 & 0 & 0 & 0 \\
\hline & 6 & 6 & 16.7 & 50.0 & 33.3 & 0 & 0 & 0 & 0 \\
\hline & 12 & 8 & 12.5 & 12.5 & 50.0 & 25.0 & 0 & 0 & 0 \\
\hline & 18 & 6 & 0 & 0 & 16.7 & 33.3 & 50.0 & 0 & 0 \\
\hline & 24 & 12 & 0 & 0 & 0 & 0 & 25.0 & 0 & 75.0 \\
\hline & 30 & 6 & 0 & 0 & 0 & 0 & 16.7 & 0 & 83.3 \\
\hline & 48 & 4 & 0 & 0 & 0 & 0 & 25.0 & 0 & 75.0 \\
\hline \multirow[t]{7}{*}{ II } & 0 & 22 & 86.4 & 13.6 & 0 & 0 & 0 & 0 & 0 \\
\hline & 6 & 7 & 28.6 & 42.9 & 28.6 & 0 & 0 & 0 & 0 \\
\hline & 12 & 6 & 16.7 & 0 & 16.7 & 66.7 & 0 & 0 & 0 \\
\hline & 18 & 16 & 0 & 0 & 12.5 & 25.0 & 12.5 & 25.0 & 25.0 \\
\hline & 24 & 8 & 0 & 0 & 0 & 12.5 & 0 & 12.5 & 75.0 \\
\hline & 30 & 11 & 0 & 0 & 0 & 9.1 & 27.3 & 0 & 63.6 \\
\hline & 48 & 11 & 0 & 0 & 0 & 0 & 72.7 & 0 & 27.3 \\
\hline \multirow[t]{7}{*}{ III } & 0 & 35 & 65.7 & 22.9 & 8.6 & 2.9 & 0 & 0 & 0 \\
\hline & 6 & 15 & 0 & 6.7 & 80.0 & 13.3 & 0 & 0 & 0 \\
\hline & 12 & 15 & 0 & 0 & 13.3 & 86.7 & 0 & 0 & 0 \\
\hline & 18 & 27 & 0 & 0 & 0 & 25.9 & 3.7 & 29.6 & 40.7 \\
\hline & 24 & 31 & 0 & 0 & 0 & 6.5 & 0 & 6.5 & 87.1 \\
\hline & 30 & 23 & 0 & 0 & 4.3 & 4.3 & 13.0 & 4.3 & 73.9 \\
\hline & 48 & 17 & 0 & 0 & 0 & 0 & 70.6 & 0 & 29.4 \\
\hline \multirow[t]{7}{*}{ IV } & 0 & 7 & 28.6 & 71.4 & 0 & 0 & 0 & 0 & 0 \\
\hline & 6 & 7 & 0 & 14.3 & 71.4 & 14.3 & 0 & 0 & 0 \\
\hline & 12 & 10 & 0 & 0 & 40.0 & 20.0 & 30.0 & 10.0 & 0 \\
\hline & 18 & 15 & 6.7 & 6.7 & 0 & 26.7 & 26.7 & 26.7 & 6.7 \\
\hline & 24 & 16 & 0 & 0 & 0 & 6.3 & 12.5 & 12.5 & 68.8 \\
\hline & 30 & 14 & 7.1 & 0 & 14.3 & 7.1 & 7.1 & 0 & 64.3 \\
\hline & 48 & 8 & 0 & 0 & 0 & 0 & 87.5 & 0 & 12.5 \\
\hline
\end{tabular}

1 The meiotic stages are defined under Materials and Methods.

of polar body presentation at $30 \mathrm{~h}$, approximately $6 \mathrm{~h}$ later than any of the other groups (Fig. 14). The peak level of first polar body occurrence was $83.3 \%, 75.0 \%, 87.1 \%$ and $68.8 \%$ for groups I, II, III and IV, respectively.

\section{Effects of hormones on oocyte maturation}

In the absence of hormones in the culture medium (Exp. $\mathrm{I}_{\mathbf{b}}$ ), oocyte maturation did proceede, as shown in the Table 4 . At 18 
T a b le 4. Cytological features of oocytes cultured in the medium with $\left(\operatorname{Exp}-\mathrm{I}_{\mathrm{a}}\right)$ or without $\left(\operatorname{Exp}-\mathrm{I}_{\mathbf{b}}\right)$ hormones.

\begin{tabular}{lcccrrrr}
\hline \multirow{2}{*}{$\begin{array}{l}\text { Type } \\
\text { of } \\
\text { medium }\end{array}$} & $\begin{array}{c}\text { Culture } \\
\text { period }\end{array}$ & $\begin{array}{c}\text { No. of } \\
\text { oocytes } \\
\text { evaluated }\end{array}$ & & \multicolumn{4}{c}{${\text { Meiotic stages }(\%)^{1}}^{1}$} \\
\cline { 5 - 7 } & & & Prometaphase $^{2}$ & M I & A-T I & M II \\
\hline with & 18 & 64 & 34.5 & 15.6 & 25.0 & 25.0 \\
hormones & 24 & 67 & 6.0 & 7.5 & 7.5 & 79.1 \\
& 30 & 54 & 13.1 & 14.8 & 1.9 & 70.4 \\
\hline without & 18 & 40 & 32.5 & 12.5 & 27.5 & 27.5 \\
hormones & 24 & 37 & 29.7 & 5.4 & 16.2 & 48.6 \\
& 30 & 33 & 51.5 & 12.1 & 3.0 & 33.3 \\
\hline
\end{tabular}

1 The meiotic stages are defined under Materials and Methods.

2 Prometaphase refers to ON I, ON II, D and LD.

h, $27.5 \%$ of oocytes reached M II stage, which was similar to the proportion achieved in the hormone-containing medium (Exp. $\mathrm{I}_{\mathrm{a}}, 25 \%$ ). At $24 \mathrm{~h}$, however, the percentage was much lower in the hormone-free medium $(48.6 \%)$ as compared with the hormone-containing medium $(79.1 \%)$. A similar decline in the percentage of M II was observed at $30 \mathrm{~h}$ (from $48.6 \%$ to $33.3 \%$ ) under hormone-free conditions.

\section{DISCUSSION}

The time sequence of bovine oocyte nuclear maturation in vitro has previously been studied by Hunter et al. (1972), Jagiello et al. (1974), Motlik et al. (1978), Süss \& Wüthrich (1985) and others. Most papers have placed their emphasis either on the early or the late meiotic stages. The present experiment provided a camplete chronology of bovine follicular oocyte maturation in vitro. It should be mentioned that the culture medium used in this study is comparable to thta used by Newcomb et al. (1978) who succeeded in obtaining two calves from follicular oocytes matured in vitro and fertilized in vivo.

In agreement with Hunter et al. (1972) we found that the majority of oocytes fixed shortly after aspiration possessed an intact oocytes nucleus $(\mathrm{ON})$. The time required for ONBD lasted from less than $6 \mathrm{~h}$ up till more than $12 \mathrm{~h}$, which is in agreement with Jagiello et al. (1974), but some what longer than those found by Motlik et al. (1978). A possible explanation for this descrepancy may be the definition of the onset of culture. 
Oocytes examined at $12 \mathrm{~h}$ were mainly in diakinesis stages with a few in Metaphase I and Ana-Telophase I stages. First polar body abstriction was observed at $15 \mathrm{~h}$ in agreement with Süss \& Wüthrich (1985), and then reached a peak level at $24 \mathrm{~h}$. Reports in the literature give a wide range of the peak period for Metaphase II occurrence, from $20 \mathrm{~h}$ (Fulka 1981), $21 \mathrm{~h}$ (Jagiello et al. 1974), 20-24 h (Süss \& Wüthrich 1985), 24-30 h (Sato 1978 ) to $31 \mathrm{~h}$ (Edwards 1965). Some of those difference are inherent to the culture conditions and methods of observation. The percentage of nuclear maturation was reportedly in the order of $60 \%$ to $85 \%$. Less than $6 \mathrm{~h}$ was required for the nuclear change from M I to M II to occur in the study, which is about $4 \mathrm{~h}$ less than found by Sato et al. (1978).

Contrary to Edwards (1965) and Hunter et al. (1972) the present study failed to reveal any block at the Metaphase I or Anaphase I stages. Thus, the requirement for substantiating at least a proper nuclear maturation was fulfilled. This includes the $\mathrm{Mg}^{++}$concentration, which is of particular interest, since Liebfried \& First (1979b) showed that absence of $\mathrm{Mg}^{++}$had a deleterious effect upon the completion of frist meiotic division.

It may under certain conditions be impossible to distinguish Metaphase II chromosomes by the whole mounting technique (Trounson et al. 1977), unless combined with the evidence of the first polar body as it was done in this study. However, when this polar body degenerates and disappears ,the Metaphase II chromosomes could be classified as Metaphase I, and this may explain why the percentage of Metaphase II showed a declining pattern after the peak.

In order to interprete the outcome of in vitro oocyte maturation, a better understanding of the heterogeneous developmental competence among the oocytes is required. Fukui \& Sakuma (1980) found that the presence of cumulus cells was the most important factor for in vitro maturation of oocytes. Dahlhausen et al. (1981) found that oocytes devoid of thier cumulus cells did not mature in vitro. In the present study, however, $68.8 \%$ of group IV oocytes (nude or partially covered oocytes) completed their first meiotic division, which is rather high in comparison with $44 \%$ from similar oocytes reported by Leibfried \& First $(1979 a)$. The reason why these denuded oocytes still have the ability to mature in vitro could be that they still possess cumulus cell projections embedded in the zona pellucida (Hyttel et al. 
1986b), from which cAMP may be transferred to the oocytes (as reviewed by Moor et al. 1983, Eppig \& Downs 1984). Whether these matured nude and/or partially nude oocytes have further developmental competence as in the mouse (Schroeder \& Eppig 1984) remains to be investigated in order to make full use of these oocytes. Previous results from sheep, however, showed that oocytes matured in the absence of all associated follicle cells did not acquire the capacity for subsequent embryonic development (Crosby et al. 1981, Staigmiller \& Moor 1984).

The fact that the maturational speed among four oocytes groups is different deserves special attention. It was shown that ONBD as well as first polarbody abstriction occurred approximately $6 \mathrm{~h}$ earlier in oocytes with few surrounding cumulus cells than in such with many cumulus cells (Figs. 13 and 14). It remains unclear whether this could be an indication that the different groups might come from different size of follicles and, thus, be at the different development stages (Dahlhausen et al. 1981, Motlik et al. 1984), or it could be an indication of a faster and easier removal of maturational inhibitor(s) (Tsafriri \& Channing 1975, Moor et al. 1983) from less covered (group II and IV) and slightly expanded (group II) oocytes.

Monitoring the ooplasm quality indicated that there was no pronounced degenerative change taking place during the culture period. On the contrary, the proportion of oocytes with finely granulated ooplasm (type I) increased, which is comparable to in vivo conditions (Greve et al. 1984) and may reflect organelle redistribution that takes place during cytoplasmic oocyte maturation in vivo (Hyttel et al 1986a) as well as in vitro (Hyttel et al. 1986b).

It is generally accepted that the preovulatory LH surge triggers the resumption of meiosis and that steroids are important for full maturation and subsequent embryonic development in vivo (Kruip et al. 1983, Dieleman et al. 1983, Callesen et al. 1986). Furthermore, both gonadotrophins and estradiol-17 $\beta$ are required for intrafollicular oocyte maturation in vitro (Moor et al. 1984). However, contradictory results regarding the role of gonadotrophins in oocyte maturation in vitro have been reported by Bae \& Foote (1975) and Flemming et al. (1985), who found that LH did not affect oocyte maturation in vitro at least of rabbits and pigs, respectively. Our results showed that in the absence of hCG and estradiol benzoate the percentage of oocytes complet- 
ing the first meiotic division declined significantly, from $79 \%$ to $49 \%$. Another striking finding was that oocytes cultured without hormones showed little cumulus expansion, a feature which is believed to be an important maturational character (Hensleigh \& Hunter 1985) (Fig. 6).

In conclusion, this study showed that a large proportion of follicular oocytes aspirated after slaughter can be matured in vitro under proper experimental conditions, and that the time sequence of events was affected by the character of the cumulus investments and the presence of hormones in the culture medium. To test the further developmental capacity, contemporary experiments at this laboratory have shown that oocytes matured under these in vitro conditions can be penetrated by bovine sperm in vitro and that the zygotes will develop to at least the pronuclear stages.

\section{REFERENCES}

Bae, In-Ha \& R. H. Foote: Effects of hormones on the maturation of rabbit oocytes recovered from follicles of various sizes. J. Reprod. Fert. 1975, 42, 357-360.

Ball, G. D., M. L. Leibfried, R. L. Ax \& N. L. First: Maturation and fertilization of bovine oocytes in vitro. J. Dairy Sci. 1984, 67, $2775-2785$.

Bornslaeger, E. \& R. M. Schultz: Regulation of mouse oocytes maturation: Effect of elevating cumulus cell cAMP on oocyte cAMP levels. Biol. Reprod. 1985, 33, 698-704.

Callesen, H., T. Greve \& P. Hyttel: Preovulatory endocrinology and oocyte maturation in superovulated cattle. Theriogenology 1986 , $25,71-86$.

Critser, E. E., M. L. Leibfried-Rutledge, W. H. Eyestone, L. L. Northey $\&$ N. L. First: Asquisition of developmental competence during maturation in vitro. Theriogenology 1986, 25, 150 (Abstr.).

Crosby, I. M., I. C. Osborn \& R. M. Moor: Follicle cell regulation of protein synthesis and developmental competence in sheep oocytes. J. Reprod. Fert. 1981, 62, 575-582.

Dahlhausen, R. D., J. B. Bonham, G. Meyers \& T. M. Ludwick: Characterization and maturation of prepuberal calf follicular oocytes in vitro. Theriogenology 1981, 15, 111 (Abstr.).

Dieleman, S. J., Th. A. M. Kruip, P. Fontijne, W. H. H. de Jong \& G. C. van der Weyden: Changes in oestradiol, progesterone and testosterone concentrations in follicular fluid and in the micromorphology of preovulatory bovine follicles relative to the peak of luteinizing hormone. J. Endocr. 1983, 97, 31-42.

Edwards, R. G.: Maturation in vitro of mouse, sheep, cow, pig, rhesus monkey and human ovairan oocytes. Nature 1965, 208, 349351. 
Eppig, J. \& S. M. Downs: Chemical signals that regulate mammalian oocyte maturation. Biol. Reprod. 1984, 30, 1-11.

Eppig, J. \& A. C. Schroeder: Culture systems for mammalian oocyte development: Progress and prospects. Theriogenology 1986, 25, 97-106.

Fleming, A. D., T. J. Kuehl \& D. T. Armstrong: Maturation of pig and rat oocytes transplanted into surrogate pig follicles in vitro. Gamete Research 1985, 11, 107-119.

Fukui, Y \& Y. Sakuma: Maturation of bovine oocytes cultured in vitro: Relation to ovarian activity, follicular size and the presence or absence of cumulus cells. Biol. Reprod. 1980, 22, 669-673.

Fulka, J., J. Motlik \& H. H. Koefoed-Johnsen: Studies on the germinal vesicle breakdown during oocyte maturation in domestic animals. In: Papers dedicated to Professor J. Moustgaard. Ed. E. Brummerstedt, Royal Vet. and Agric. University, Royal Danish Agric. Soc., Copenhagen 1981, pp. 178-185.

Greve, T., D. Bousquet, W. A. King \& K. J. Betteridge: In vitro fertilization and cleavage of in vivo matured bovine oocytes. Theriogenology 1984, 22, 151-165.

Hensleigh, H. C.\& A. G. Hunter: In vitro maturation of bovine cumulus enclosed primary oocytes and their subsequent in vitro fertilization and cleavage. J. Dairy Sci. 1985, 68, 1456-1562.

Hunter, R. H.F., R. A.S. Lawson \& L. E. A. Rowson: Maturation, transplantation and fertilization of ovarian oocytes in cattle. J. Reprod. Fert. 1972, 30, 325-328.

Hyttel, P., H. Callesen \& T. Greve: Ultrastructural features of preovulatory oocyte maturation in superovulated cattle. J. Reprod. Fert. 1986a, 76, 645-656.

Hyttel, P., K. P. Xu, S. Smith \& T. Greve: Ultrastructure of in vitro oocyte maturation in cattle. J. Repro. Fert. 1986b, 78, 615-625.

Jagiello, G. M., W. A. Miller, M. B. Ducayen \& J. S. Lin: Chiasma frequency and disjunctional behaviour or ewe and cow oocytes matured in vitro. Biol. Reprod. 1974, 10, 354-363.

Kruip, T. A. M., D. G. Cran, T. H. van Beneden \& S. J. Dieleman: Structural changes in bovine oocytes during final maturation in vitro. Gamete Research. 1983, 8, 29-47.

Lambert, R. D., M. A. Sirard, C. Bernard, R. Beland, J. E. Rioux, P. Leclerc, D. P. Menard \& M. Bedoya: In vitro fertilization of bovine oocytes matured in vivo and collected at laparoscopy. Theriogenology 1986, 25, 117-133.

Leibfried, L. \& N. L. First: Characterization of bovine follicular oocytes and their ability to mature in vitro. J. Anim. Sci. 1979a, 48, $76-86$.

Leibfried, L. \& N. L. First: Effects of divalent cations on in vitro maturation of bovine oocytes (1). J. Exp. Zool. 1979b, 210, $\mathbf{5 7 5}-\mathbf{5 8 0}$.

Leibfried-Rutledge, M. L., E. S. Critser \& N. L. First: Fertilization potential of follicular oocytes classified by stage of cycle and size of follicle. Theriogenology 1985, 23, 753-759. 
Moor, R. M., I. C. Osborn \& I. M. Crosby: Cell interactions and oocyte regulation in mammals. In: Roland, R., E. V,. van Hall, S. G. Hillier, K. O. McNatty, J. Shoemaker (eds): "Follicular maturation". Amsterdam: Excerpta Medica, Elsevier/North-Holland 1981, pp. $249-264$.

Moor, R. M., I. M. Crosby \& J. C. Osborn: Growth and maturation of mammalian oocytes. In: vitro fertilization and embryo transfer. Proc. Serono Clinical Colloquia on Reproduction, no. 4, ed. Crosignani \& B. L. Rubin. Academic Press 1983, pp. 39-63.

Moor, R. M., Th. A. M. Kruip \& D. Green: Intraovarian control of folliculogenesis: Limits to superovulation? Theriogenology 1984, 21, 103-116.

Motlik, J., H. H. Koefoed-Johnsen \& J. Fulka: Breakdown of the germinal vesicle in bovine oocytes cultured in vitro. J. exp. Zool. 1978, 205, 377-384.

Motlik, J., N. Crozet \& J. Fulka: Meiotic competence in vitro of pig oocytes isolated from early antral follicles. J. Reprod. Fert. 1984, 72, 323-328.

Motlik, J. \& J. Fulka: Factors affecting meiotic competence in pig oocytes. Theriogenology 1986, 25, 87-96.

Newcomb, R., W. B. Christie \& L. E. A. Rowson: Birth of calves after in vivo fertilization of oocytes removed from follicles and matured in vitro. Vet. Rec. 1978, 102, 461-462.

Sato, Eimei, Akira Iritani \& Yoshimasa Nishkawa: Maturation and activitation of cattle follicular oocytes cultured in vitro. Jap. J. Zootech. Sci. 1978, 49, 236-242.

Schroeder, A. C. \& J. Eppig: The developmental capacity of mouse oocytes that matured spontaneously in vitro is normal. Dev. Biol. 1984, 102, 493-497.

Staigmiller, R. B. \& R. M. Moor: Effect of follicle cells on the maturation and developmental competence of ovine oocytes matured outside the follicle. Gamete Research 1984, 9, 221-229.

Süss, U. \& K. Wüthrich: Stages of the first meiotic division observed in bovine oocytes matured in vitro. Theriogenology 1985, 23, 231 (Abstr.).

Trounson, A. O., S. M. Willadsen \& L. E. A. Rowson: Fertilization and development capacity of bovine follicular oocytes matured in vitro and transferred to the oviducts of rabbits and cows. J. Reprod. Fert. 1977, 51, 321-327.

Tsafriri, A. \& C. P. Channing: An inhibitory influence of granulosa cells and follicular fluid upon porcine oocyte meiosis in vitro. J. Endocr. 1975, 96, 922—927.

\section{SAMMENDRAG}

Kronologiske ændringer $i$ bovine follikulære oocyter modnet in vitro.

Oocytmodningens kronologiske forl $\varnothing \mathrm{b}$ blev studeret efter in vitro modning af slagtehusoocyter. Deres cumulus oophorus, perivitelline rum st $\varnothing$ rrelse samt cytogenetiske karakteristika blev unders $\varnothing$ gt umid- 
delbart efter aspiration (kontroloocyter) og efter dyrkning i henholdsvis $6,12,18,21,24,27,30$ og 48 timer i Ham's F-10 medium eller Ham's F-10 medium tilsat humant chorion-gonadotropin (hCG) og $\emptyset$ stradiolbenzoat (EB). Resultaterne viste, at oocytkernen blev nedbrudt (ONBD) inden for de første 6-12 timer, og at hovedparten af oocyterne afsn $\emptyset$ rede deres f $\varnothing$ rste pollegeme (PB1) efter 24 timers dyrkning in vitro. Begge disse processers tidsmæssige forløb var påvirket af cumuluscellelagenes antal og tæthed, således at oocyter omgivet af mange lag, tætsluttende cumulusceller brugte længere tid både til ONBD og til udstødelse af PB1.

Oocytmodningen var ligeledes under indflydelse af dyrkningsmediets hormonindhold, idet Ham's F-10 med hCG og EB resulterede i en højere modningsrate $(79,1 \%)$ and Ham's F-10 uden hormoner $(48,6 \%)$, bl. a. fordi en stor procentdel af oocyterne tilh $\varnothing$ rende denne sidste gruppe ikke nảede metafase II stadiet, men standsede ved metafase I og anafase-telofase I.

Nærværende unders $\emptyset$ gelse har vist, at en meget $h \emptyset j$ procentdel af slagtehusoocyter kan modnes in vitro, at tilsætning af hormoner samt cumuluscellelagenes antal og tæthed påvirker det kronologiske forl $\emptyset \mathrm{b}$ af denne proces.

(Received July 10, 1986).

Reprints may be requested from: T. Greve, the Department of Animal Reproduction, Royal Veterinary and Agricultural University, Bülowsvej 13, DK-1870 Frederiksberg C, Denmark. 